\title{
Development of Auditory Training Tool for Adults Using Sentences
}

\author{
Sunghwan Chang, Junghak Lee \\ Department of Audiology, Hallym University of Graduate Studies, Seoul, Korea
}

\section{문장을 이용한 일반용 청능훈련 도구개발}

\author{
장 성 환 ·이 정 학 \\ 한림국제대학원대학교 청각학과
}

\begin{abstract}
Purpose: The purpose of this study was to develop a list of sentences for auditory training, especially speech tracking for hearingimpaired adults. Methods: A total of 1,000 sentences which were collected from five popular novels, were recorded on a compact disk. Seventy-five hundred basic sentences were selected based on the validity test and 750 noise sentences were made by synthesizing basic sentences with 4-talker babble noise. Participants were 20 young and 20 elder people who spoke Korean as their first language. Results: Results showed that all 750 basic sentences scored greater than 90\% of correct response rate. However, 138 noise sentences scored lower than $90 \%$ of correct response rate. In 750 noise sentences, there were significant differences in correct response rate with respect to the number of words in each sentence, age, and speaker. Conclusion: These results recommend that newly developed 750 basic sentences are appropriate in speech tracking for adult auditory training. For noise sentences, however, 618 sentences are recommended for speech tracking.
\end{abstract}

Key Words: Auditory training, Speech tracking, Basic sentences, Noise sentences.

Received: March 7, 2016 / Revised: April 10, 2016 / Accepted: April 13, 2016

Correspondence: Junghak Lee, Department of Audiology, Hallym University of Graduate Studies, 405 Yeoksam-ro, Gangnam-gu, Seoul 06198, Korea Tel: +82-2-2051-4950 / Fax: +82-2-3453-6618 / E-mail: leejh@hallym.ac.kr

\section{INTRODUCTION}

난청의 문제를 해결할 수 있는 방법으로 가장 우선시되는 방 법은 보청기를 착용하거나 인공와우의 이식을 고려할 수 있다. 인공와우는 고심도 이상의 난청에 적용하고 수술 부담도 있어, 대부분의 후천성 난청의 경우에는 보청기를 착용하고 청능재활 을 실시하고 있다. 하지만, 상당수 보청기 구매자들은 초기적합 이후에 보청기를 사용하지 않는 것으로 나타나고 있다(Kochkin, 2005; Koo et al., 2006). Koo et al.(2006)의 연구에 의하 면 보청기 착용을 거부한 가장 큰 이유가 보청기 착용 효과가 작다는 점이었으며, Kochkin(2005)의 조사결과에 따르면 소음 하에서의 사용에 대한 불만족도가 전체 요인 중 $35 \%$ 로 가장 높게 나타났다. 이는 보청기가 1:1 대화나 조용한 환경에서는 상 당한 효과가 있지만 보청기 소리에 익숙한 난청인에게도 다중 화자 시에는 만족할 만한 효과를 주지 못하는 듯하다.
소음하에서 말소리를 잘 이해하기 위해서는 먼저 신호 대 잡 음비(signal-to-noise ratio, SNR) 개선을 위한 방향성 마이크, 소음 감소 알고리즘 등의 개발이 무엇보다도 중요하다(Burk \& Humes, 2008; Lee \& Lee, 2008). 하지만 이 연구들은 지속적 인 청능훈련(auditory training)을 통한 인지능력의 향상도 기 술적 발전 못지 않게 중요하다는 점도 강조하고 있다. 특히 Lee $\&$ Lee(2008)는 난청인의 만족도를 높이기 위해서는 보청기의 최신기술과 난청의 특성을 충분히 숙지하고 있는 청각전문가가 개별화 계획에 근거하여 청능훈련을 시행해야 한다고 주장하 고 있다. 이처럼 국내외의 연구자들은 소음 하에서 의사소통의 어려움을 해결하기 위해 난청인에게 적절한 청능훈련이 상당히 효과적이라는 해결안을 제시하고 있다. 실제적으로 청능훈련을 받은 그룹은 소음 하 문장인지도가 유의미하게 향상되었고 훈 련에 사용되지 않은 소음 하 인지도까지도 향상되어 청능훈련 효과가 일반화되었다는 보고(Yeo et al., 2014)도 있다. 또한 
Kwon(2013)은 8주간의 청능훈련이 소음 하 어음 인지력과 사 용보청기의 주관적 만족도의 향상에 영향을 주는 것으로 보고 하였다.

최근 국내에서는 소음 하 청능훈련에 대한 중요성이 부각되 어 훈련프로그램의 개발 및 연구에 대한 필요성이 대두되고 있 다. 특히 대화체 문장을 듣고 따라 말하는 말추적(speech tracking)은 청능훈련에서 널리 사용되는 방법 중 하나인데(De Filippo \& Scott, 1978), 우리나라에서도 이 방법을 사용한 연 구들이 있다(Kwon, 2013; Yeo et al., 2014). 하지만 이 연구들 은 말추적 청능훈련을 주로 소음 하 한국어문장인지(Korean Speech Intelligibility in Noise, KSPIN) 검사도구(Kim et al., 2000)에 수록되어 있는 문장목록으로 진행하였기 때문에 난청 인이 지루해 하였다고 보고하였다. 이에 본 연구에서는 난청인들 이 지루해하지 않고 도전감을 가질 수 있도록 난이도를 고려한 다양한 내용의 말추적 청능훈련용 문장목록을 개발하고자 하 였다. 구체적으로는 소음 없는 문장과 소음합성 문장을 개발하 여 각 문장의 어절수, 연령대 및 화자에 따른 정답률을 제시함으 로써 청능훈련을 보다 효율적으로 진행할 수 있도록 하였다.

\section{MATERIALS AND METHODS}

\section{문장목록 및 음원 개발}

\section{문장목록 수집}

난청인의 청능훈련용 문장목록의 개발이라는 연구의 취지에 부합하도록 일상생활에서의 사용 빈도수가 높으며 가능한 한 쉽고 다양한 표현의 문장들을 수집하기 위해 대한민국 대표작 가 5명의 소설 중에서 주로 가족사를 다룬 소설을 선정하였다. 문장의 길이는 어절 수를 기초로 하여 조절하였으며 문장의 길 이가 너무 길면 이해도 저하에 의한 효과반감을 예상하여 최소 3 어절, 최대 6어절로 제한하였다. 또한, 최대한 자연스러움을 유 지하기 위해서 소설 속의 문장을 가급적 그대로 사용하였다. 마지막으로 소설 특성상 남, 여 작가의 문체가 다른 점을 고려 하여 성비를 맞추려고 노력했으며(남 2명, 여 3명) 한 작가 작품 의 표현에만 편중되지 않도록 하기 위해 소설 한 권당 3 4어절 의 단문 100 개, 5 6어절의 장문 100 개, 합계 200 문장씩 발췌하 여 총 1,000 문장을 1 차적으로 수집하였다. 문장목록의 수집을 위해 사용된 소설은 신경숙 「엄마를 부탁해」, 공지영 「즐거운 나의 집」, 황석영 「강남몽」, 박완서「친절한 복희씨」, 김훈「공무 도하,였다.

\section{문장목록 타당성 검증}

수집한 문장목록의 타당성 검증을 위해서 한국어를 모국어
로 사용하고 현재 개인센터나 복지관 등에서 직접적으로 난청 인에게 청능훈련을 시행하고 있는 청각학과 대학원생 5명(남 2 명, 여 3명)이 참가했으며 연령범위는 28 38세(평균 33.4세)였 다. 타당성 검증방법은 수집한 1,000 문장을 무작위로 배열한 후 평가 검증자 5 명에게 청능훈련용으로 사용하기에 적절한지에 대한 사전 설문 조사를 실시하였다. 한 문장당 1점에서 5점까 지 점수화하였으며 5 명의 평균점수를 계산하였다. 점수부여의 기준은 난청인의 청능훈련용 문장으로 사용하기에 매우 적절 하다(5점), 적절하다(4점), 보통이다(3점), 적절하지 않다(2점), 매우 적절하지 않다(1점)이다.

\section{문장목록 선정}

타당성 검증을 통해 전체 1,000 문장 중 점수가 낮은 250 문 장을 제외하였다. 최종적으로 단문 406개, 장문 344개 합계 750 문장을 청능훈련용 문장목록으로 선정하여 평균 타당성점 수가 높은 문장에서 낮은 문장 순서대로 배열하였고 처음 50 개 문장을 예시로 제시하였다(Appendix).

\section{문장목록 $\mathrm{CD}$ 음원 제작}

선정된 750 문장목록의 $\mathrm{CD}$ 음원 녹음을 위해 3 명(남 1명, 여 2명)의 건청 성인(연령범위 27 35세)이 화자로 참여하였다. 화자 모두 한국어를 모국어로 하였고 표준어를 사용하였으며 언어 및 조음장애가 없었다. 먼저 음성분석기(Computerized Speech Lab, CSL 4500, Kay Pentax)를 이용하여 50문장씩 녹음하고 휴식 시간을 가진 후 계속하였다. 녹음한 문장은 음 성편집기(Cool Edit Pro 2.1)를 이용하여 문장 단위로 구분하 여 각 문장의 진폭 범위를 최대한 비슷하도록 조정하였다(20 $\mathrm{dB})$. 또한 소음 없는 750 문장에 소음을 $0 \mathrm{~dB}$ SNR로 합성한 750 문장도 동일한 방법으로 각 문장의 진폭 범위가 유사하도 록 조절하였다. 이러한 처리과정을 통해서 소음 없는 750 문장과 소음합성 750 문장, 총 1,500 문장의 $\mathrm{CD}$ 음원을 제작하였다. 이 때 녹음은 방음실에서 진행하였으며 화자 입의 위치는 스탠드 마이크 정면의 동일한 높이에서 $15 \mathrm{~cm}$ 정도 떨어진 거리에 두 고 최대한 편안한 상태로 앉아서 진행하였다. 음원의 순서는 여-여-남 3명으로 250문장씩 총 750문장을 녹음하였고 소음 원은 Shin \& Lee(2010)가 개발한 다화자 소음(babble noise)을 사용하였다.

\section{문장목록 평가}

\section{대상자}

본 연구의 대상자는 총 40 명으로 청년층 20 명(남 11 명, 여 9 명)과 장년층 20 명(남 11 명, 여 9 명)이 참여하였다. 청년층의 연 
령범위는 23 30세(평균 26.4세)였으며 장년층의 연령범위는 50 68세(평균 59.9세)로 참가자 모두 문장목록 $\mathrm{CD}$ 녹음작업 의 화자로 참여하지 않았다. 이 연구의 참가자 조건은 첫째, 세 주파수 $(500,1,000,2,000 \mathrm{~Hz})$ 에서 평균 순음 역치(pure tone threshold average)가 $30 \mathrm{~dB}$ HL 이하이며 둘째, 단어인지도 (word recognition score)가 80\% 이상이고 셋째, 고막운동검사 (tympanometry)에서 A형이며, 마지막으로 큰 소음에 장시간 노출된 경험이 없는 건강한 사람들이었다.

\section{장비 및 도구}

청력측정은 보정을 실시한 청력검사기 2대(Grason-Stadler, GSI 61; Ento med AB, SA 204, Eden Prairie, MN, USA)로 시행하였고, 고막운동검사는 이미턴스검사기 2대(Interacoustics, AT235h; Amplivox, Autowave 102, Middelfart, Denmark)를 사용하였다. 상기한 소음합성 750 문장 목록과 소음 없는 750 문장 목록의 $\mathrm{CD}$ 음원을 평가도구로 사용하였다.

\section{절 차}

실제 언어생활이 어느 정도의 소음이 존재하고 있는 상황에 서 이루어지는 점을 고려하여 방음실이 아닌 10 평 내외 40 $\mathrm{dBA}$ 이하의 조용한 상담실 또는 강의실에서 따라 말하도록 요 청하였다. 말소리 제시 레벨은 보통 목소리 크기(45 dB HL)로 스피커를 통해 소음합성 750 문장 목록을 먼저 들려주었다. 평 가 특성상 장시간이 요구되는 관계로 진행 중 집중도 저하로 인 해 문장을 듣지 못한 경우를 배려하여 1차적으로 틀린 문장에 대해서는 2 3번 정도 더 들려주었다. 반복 청취 후에도 정확히 따라하지 못한 소음합성 문장에 대해서는 소음 없는 문장음원 을 들려주어 문장단위로 정반응율을 계산하였다. 소음합성 문 장에서 정반응을 보인 경우 소음 없는 문장은 검사하지 않고 정 반응으로 간주하였다.

\section{자료분석}

두 검사 조건에서 750 개 각 문장에 대하여 청년층과 장년층 의 정답율과 평균 및 표준편차를 구하였다. 또한 문장목록의 어절 수에 따른 정답률은 대응표본 $t$-검정, 연령대에 따른 정답 율은 독립표본 $t$-검정, 화자에 따른 정답률은 일원분산분석으 로 비교하였으며 전체적인 통계 처리는 SPSS 20.0(IBM, Chicago, IL, USA)를 이용하였다.

\section{RESULTS}

\section{전체 정답률 추이}

당성 점수가 높은 순서대로 1 750번까지 문장을 차례로 배
열하여 소음 없는 문장목록과 소음합성 문장목록의 정답률 추 이를 살펴보았다. 먼저 소음없는 문장목록은 $99.9 \%$ 의 정답률 을 보였으며 표준편차는 $0.1 \%$ 로 나타났다. 750 개 모두 $90 \%$ 이 상의 정답률을 보였으며, 9 개 문장에서 오류가 나타났다. 소음 합성 문장목록에서는 $93.7 \%$ 의 정답률을 보였으며, 표준편차는 $4.7 \%$ 로 나타났다. $90 \%$ 이상의 정답률을 보인 문장은 612 개였 고, $80 \%$ 이상 $90 \%$ 미만의 정답률을 보인 문장은 47 개, $80 \%$ 미 만의 정답률을 보인 문장은 91개였다(Table 1).

\section{어절 수에 따른 정답률 차이}

먼저 750문장의 어절 분포를 살펴보면 3 4어절의 단문이 406문장, 5 6어절의 장문이 344문장이다(Table 2). 소음 없는 문장목록의 경우 단문, 장문 동일하게 $99.9 \%$ 의 정답률과 $0.1 \%$ 의 표준편차를 보였다. 모두 $90 \%$ 이상의 정답률을 나타냈으며 어절 수에 따른 큰 변화는 보이지 않았다. 소음합성 문장목록의 경우 단문에서 $95.7 \%$ 의 정답률과 $2.9 \%$ 의 표준편차를 보였고, 장문에서는 $91.2 \%$ 의 정답률과 $6.9 \%$ 의 표준편차를 보였다

Table 1. Correct response rates for all subjects in sentence lists with vs. without noise

\begin{tabular}{ccc}
\hline Correct response rates & $\begin{array}{c}\text { Lists without noise } \\
\text { (unit: sentence) }\end{array}$ & $\begin{array}{c}\text { Lists with noise } \\
\text { (unit: sentence) }\end{array}$ \\
\hline$\geq 90 \%$ & 750 & 612 \\
$80-89 \%$ & 0 & 47 \\
$<80 \%$ & 0 & 91 \\
Total & 750 & 750 \\
\hline
\end{tabular}

Table 2. Correct response rates with respect to the length of sentence in lists with vs. without noise

\begin{tabular}{cccccc}
\hline \multirow{2}{*}{$\begin{array}{c}\text { Correct } \\
\text { response rates }\end{array}$} & \multicolumn{2}{c}{$\begin{array}{c}\text { Lists without noise } \\
\text { (unit: sentence) }\end{array}$} & & \multicolumn{2}{c}{$\begin{array}{c}\text { Lists with noise } \\
\text { (unit: sentence) }\end{array}$} \\
\cline { 2 - 3 } \cline { 6 - 6 } & Short & Long & & Short & Long \\
\hline$\geq 90 \%$ & 406 & 344 & & 353 & 259 \\
$80-89 \%$ & 0 & 0 & & 24 & 23 \\
$<80 \%$ & 0 & 0 & & 29 & 62 \\
Total & 406 & 344 & & 406 & 344 \\
\hline
\end{tabular}

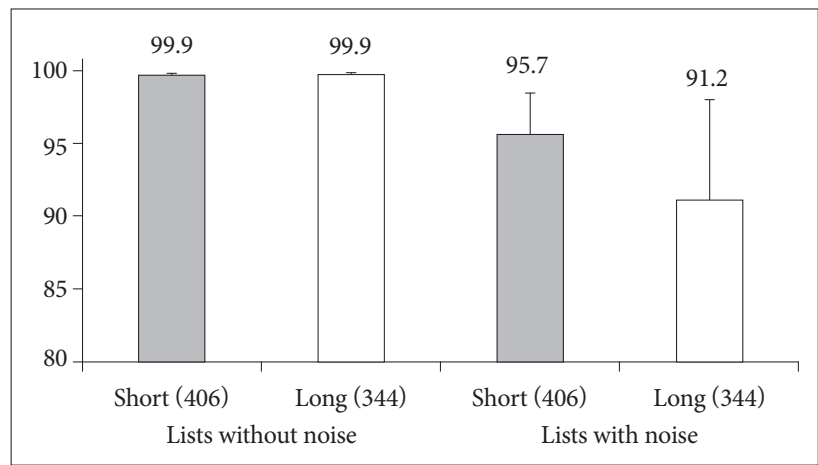

Figure 1. Means and standard deviations of correct response rates with respect to the length of sentence in lists with vs. without noise. 
(Figure 1). 이는 소음합성 문장목록의 경우 어절의 길이가 정 답률에 영향을 미치고 있음을 알 수 있다. 실제 정답률이 $90 \%$ 미만을 나타냈던 138개의 문장 중에 5 6어절의 장문은 85개, $3 \sim 4$ 어절의 단문은 53 개였으며, $80 \%$ 미만을 나타냈던 91 개의 문장 중에 5 6어절은 62개, 3 4어절은 29개로 단문에 비해 장 문의 수가 두 배 이상이나 많았다(Table 2).

소음합성 문장목록에서는 전체 피검자를 대상으로 장문과 단문을 비교한 대응표본 $t$-검정 결과 유의미한 차이 $[t(39)=$ $-6.116, p<0.01]$ 를 보였다. 즉, 어절 수에 따라 정답률은 영향 을 받으며 3 4어절의 단문보다는 5 6어절의 장문에서 더 낮은 정답률을 보였다.

\section{연령대에 따른 정답률 차이}

소음 없는 문장목록의 경우 청년층, 장년층 모두 $90 \%$ 이상 의 정답률을 나타냈으며 청년층(20 30대)과 장년층(50 60대) 그룹 모두 동일하게 정답률 $99.9 \%$, 표준편차 $0.1 \%$ 를 보였다. 소 음문장목록에서는 청년층의 경우 $96.6 \%$ 의 정답률과 $2.1 \%$ 의 표준편차, 장년층의 경우는 $90.9 \%$ 의 정답률과 $4.9 \%$ 의 표준편 차를 보였다(Figure 2). 소음문장목록에서 청년층과 장년층을 비교한 Levene의 등분산 검정 결과, 유의확률이 0.05 보다 작아 등분산이 가정되지 않았다. 따라서 등분산이 가정되지 않는 독립 표본 $t$-검정 결과 연령에 따른 정답률에 유의미한 차이 $[t(25.487)$ $=-4.729, p<0.01]$ 를 보였다. 즉, 연령에 따라 정답률은 영향을

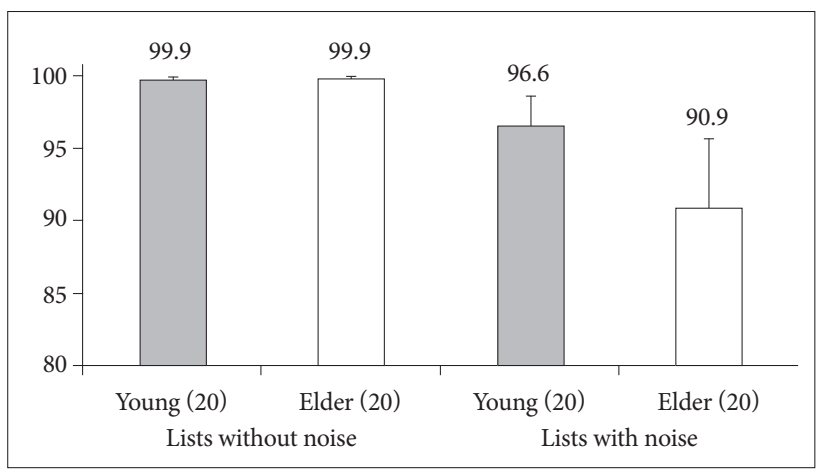

Figure 2. Means and standard deviations of correct response rates with respect to age in sentence lists with vs. without noise.

Table 3. Correct response rates with respect to age in sentence lists with vs. without noise

\begin{tabular}{|c|c|c|c|c|c|c|c|c|}
\hline \multirow{3}{*}{$\begin{array}{l}\text { Correct } \\
\text { response rates }\end{array}$} & \multicolumn{4}{|c|}{$\begin{array}{l}\text { Lists without noise } \\
\text { (Unit: sentence) }\end{array}$} & \multicolumn{4}{|c|}{$\begin{array}{l}\text { Lists with noise } \\
\text { (Unit: sentence) }\end{array}$} \\
\hline & \multicolumn{2}{|c|}{ Young } & \multicolumn{2}{|c|}{ Elder } & \multicolumn{2}{|c|}{ Young } & \multicolumn{2}{|c|}{ Elder } \\
\hline & Short & Long & Short & Long & Short & Long & Short & Long \\
\hline$\geq 90 \%$ & 406 & 344 & 406 & 344 & 380 & 301 & 348 & 250 \\
\hline $80-89 \%$ & 0 & 0 & 0 & 0 & 13 & 23 & 19 & 17 \\
\hline$<80 \%$ & 0 & 0 & 0 & 0 & 13 & 20 & 39 & 77 \\
\hline Total & 406 & 344 & 406 & 344 & 406 & 344 & 406 & 344 \\
\hline
\end{tabular}

받으며 청년층보다는 장년층에서 더 낮은 정답률을 보였다.

문장의 길이에 따른 정답률은 청년 장년 모두 소음 없는 목록 에서는 단문(406개)과 장문(344개) 모두에서 $90 \%$ 이상이었다. 하지만 소음합성 목록에서는 장년의 경우 344 개의 장문에서 $90 \%$ 미만의 정답률을 보인 문장이 94 개, 청년의 경우는 43 개 였으며, $80 \%$ 미만은 장년은 77 개, 청년은 20개로 상당한 차이 를 보였다(Table 3).

\section{어절 수와 연령에 따른 정답률 비교분석}

소음 없는 문장목록의 단문, 장문에서의 청년층과 장년층의 정답률과 표준편차는 모두 각각 $99.9 \%, 0.1 \%$ 로 동일하게 나타 났다. 소음합성 문장목록의 경우 단문에서 청년층은 $97.4 \%$ 의 정답률과 $1.7 \%$ 의 표준편차, 장년층은 $94.1 \%$ 의 정답률과 $3.12 \%$ 의 표준편차를 나타냈다. 또한 장문에서 청년층은 $95.5 \%$ 의 정 답률과 $2.9 \%$ 의 표준편차, 장년층은 $87.1 \%$ 의 정답률과 $7.2 \%$ 의 표준편차로 단문보다 장문에서 보다 큰 연령대 간 차이가 나타 났다(Figure 3).

\section{화자에 따른 정답률 차이}

소음 없는 문장목록의 경우 화자별 단문, 장문 모두에서 정

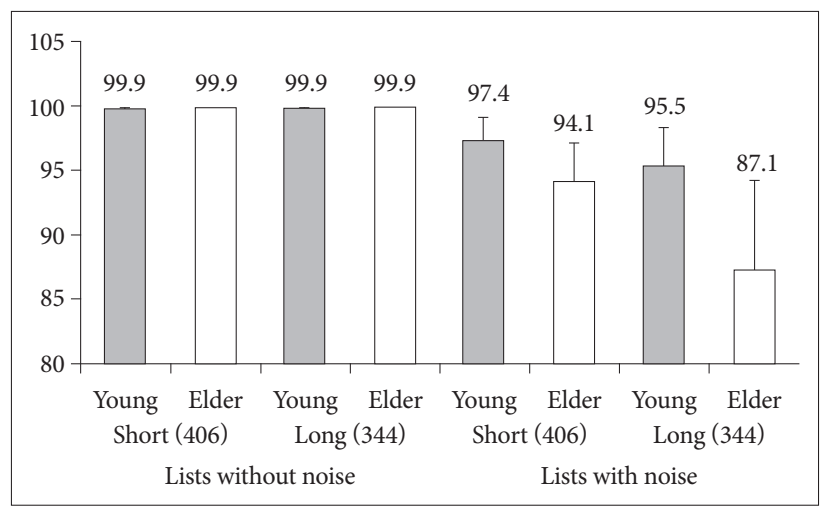

Figure 3. Means and standard deviations of correct response rates with respect to length of sentence and age in sentence lists with vs. without noise.

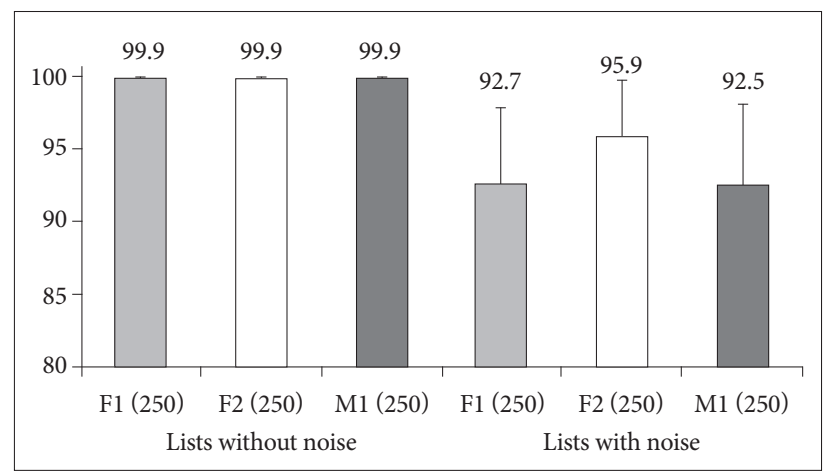

Figure 4. Means and standard deviations of correct response rates with respect to speaker in sentence lists with vs. without noise. 
답률 99.9\%, 표준편차 $0.1 \%$ 로 화자에 따른 차이는 보이지 않았 다. 소음합성 문장목록에서는 F1 화자는 정답률 $92.7 \%$, 표준편 차 $5.2 \%, \mathrm{~F} 2$ 화자는 정답률 $95.9 \%$, 표준편차 $3.9 \%, \mathrm{~F} 3$ 화자는 정답률 $92.5 \%$, 표준편차 $5.6 \%$ 를 나타냈다(Figure 4).

소음합성 목록문장에서는 전체 피검자를 대상으로 화자 간 을 비교한 일원분산분석 결과 구형성 가정된 $\mathrm{F}$ 값을 기준하여 $[\mathrm{F}(2,78)=44.8, p<0.05]$ 로 화자에 따라 정답률에 유의미한 차이를 보였으며 특히 F2 화자의 문장목록에 청년층, 장년층 모 두 더 높은 정답률을 나타냈다. 이는 문장의 타당도, 어절 수의 길이와 함께 화자의 발음과 음원의 녹음상태가 정답률에 적지 않은 영향을 미치고 있음을 시사한다.

\section{DISCUSSIONS}

연구에서는 난청인들에게 있어 보다 다양하고 실제적으로도 청능재활에 큰 도움을 줄 수 있는 문장들을 체계적인 과정을 통해 수집 및 평가하여 본격적인 청능훈련용 문장도구를 개발 하고자 하였다. 이 연구를 통하여 개발한 훈련용 문장도구는 소음 없는 문장목록 750 개와 소음합성 문장목록 750 개 총 1,500 문장으로 구성되어 있다. 실제적으로 난청인의 청능훈련 도구로서의 사용에 앞서 청년층 20명(20 30대)과 장년층 20명 (50 60대)의 건강한 성인 40명에게 사전평가를 실시한 결과, 소음 없는 문장목록에서는 750 문장 중 741 문장에서 $100 \%$ 의 정답률을 보였으며 6명으로부터 9문장의 오류를 보였지만, 750 문장 모두 $90 \%$ 이상의 정답률을 보여서 조용한 환경에서는 연 령에 상관없이 청년층, 장년층 모두 청능훈련 도구로서 사용하 는 데 큰 무리가 없을 것으로 판단한다. 반면, 소음합성 문장목 록에서는 750 문장 중 524 문장에서 $100 \%$ 정답률을 보였으며, 226 문장에서 오류가 나타났다. $90 \%$ 이상의 정답률을 보인 612 문장은 훈련도구로 사용함에 있어 문제가 없을 것으로 판단되 며, $80 \%$ 이상 $90 \%$ 미만의 정답률을 보인 47 문장의 경우 상황 에 따라서 사용할 것을 권장한다. 또한 $80 \%$ 미만의 정답률을 보인 91문장은 주로 소음과 문장이 겹쳐져 단어가 잘 들리지 않은 경우가 대부분으로 이러한 문장은 청능훈련 시 사용하지 않는 편이 좋을 것이다.

다음으로 750 문장 목록의 어절 수에 따른 차이를 대응표본 $t$-검정을 통해, 연령에 따른 차이를 독립표본 $t$-검정을 통해 살 펴본 결과, 소음합성 문장목록에서 어절 수 및 연령에 따라 정 답률에 유의미한 차이가 있음을 확인할 수 있었다. 즉, 실제적 으로 750 소음합성 문장목록을 난청인들의 훈련도구로 사용할 때에는 3 4어절의 단문부터 먼저 적용하고 5 6어절의 장문을 나중에 사용하는 것이 자연스러울 것이다. 또한 청년층과 장년 층의 정답률에 상당한 차이가 나는 부분을 고려하여 연령 특
성에 따른 청능훈련 계획을 잘 세워서 보다 체제적으로 접근한 다면 난청인들의 재활에 상당한 도움이 될 것으로 예상한다. 마지막으로 화자에 따른 차이를 일원분산분석을 통해 살펴본 결과 소음합성 문장목록에서 화자에 따라 정답률에 유의미한 차이를 보였으며 특히 F2의 경우가 가장 높은 정답률을 보였는 데 이 부분 역시 청능훈련 시 고려되어야 할 항목이다. F2에서 가장 높은 정답률을 보인 이유로는 F2 화자가 다른 화자에 비 해 전반적으로 발음과 성량이 정확하고 풍부했으며 무엇보다 소음과의 합성 시 문제되는 단어가 적었다.

실제적으로 이번에 개발된 문장목록은 총 750 문장에 달하 는 다양한 내용의 문장과 다화자 소음을 합성한 난이도 구성 으로 청능재활을 받는 난청인들이 덜 지루해하고 난이도 조절 을 통해서 성취감을 느낄 수 있도록 하는 데 역점을 두었다. 또 한 이번에 개발한 문장목록은 기존에 청능평가 목적으로 개발 된 KSPIN 검사도구(Kim et al., 2000)와는 달리 청능훈련용 도구라는 점과 다양성을 추가하였다는 점에서 큰 의미가 있으 며, 실제 난청인의 재활도구로서 상당히 효과적으로 사용될 수 있을 것으로 기대한다. 이 연구에서 재활문장을 수집하는 과정 에 있어 대한민국을 대표하는 다섯 작가의 작품 중 일상생활에 서 사용빈도가 높을 것으로 추측되는 문장을 중심으로 발췌하 려고 노력했으나 다음과 같은 한계성을 지니고 있다. 즉, 소설이 라는 장르 특성상 문체가 다소 딱딱한 점, $\mathrm{CD}$ 음원을 녹음하 는 과정에서 마이크와 화자 간의 거리만을 고려했을 뿐 화자의 성량, 말의 속도 등, 화자 개인의 성향을 충분히 감안하지 못한 점, 마지막으로 1,500 문장 목록의 평가 시간이 최소 2 시간에서 최대 4시간까지 소요되어 피검자의 집중력저하 또는 지루함을 충분히 고려하지 못했던 점 등을 포함한다. 따라서 앞으로도 청능재활의 필요성과 더불어 더 다양하고 재미있는 말추적 청 능훈련용 문장목록들의 개발이 이번 연구의 제한점들을 보완 하여 이루어진다면 난청인들에게 보다 효율적인 청능훈련 도구 로서 자리매김 할 수 있을 것이다.

본 연구에서는 난청인의 의사소통 개선을 위한 말추적 청능 훈련용 문장목록을 개발하여 $\mathrm{CD}$ 음원으로 제작하였다. 이 목 록을 20 30대 청년층 20명과 50 60대 장년층 20명, 총 40명의 건강한 성인에게 제시하여 다음과 같은 결론을 얻었다.

첫째, 소음 없는 문장은 750 개 모두 90\% 이상의 정답률을 보였기 때문에 청능훈련도구로 사용이 가능할 것이다. 둘째, 소 음합성 문장은 어절 수, 연령대 및 화자에 따라서 정답률에 상 당한 차이를 보였기 때문에 청능훈련 조건에 따라서 적절한 문 장도구를 사용해야 할 것이다. 즉, 각 조건에서 $90 \%$ 이상의 정 답률을 보인 문장의 경우 청능훈련도구로서의 사용이 적절할 것이며 80 90\% 정답률을 보인 문장은 개별적 상황에 따라 사 용 가능할 것이다. 하지만 $80 \%$ 미만의 정답률을 보인 문장은 
청능훈련도구로서 사용이 적절하지 않다고 본다. 마지막으로 향후 보다 흥미롭고 다양한 컨텐츠를 개발하면 난청인의 의사 소통 개선에 더욱 이바지할 것으로 기대한다.

중심 단어 : 청능훈련·말추적·기본문장·소음문장.

\section{REFERENCES}

Burk, M. H. \& Humes, L. E. (2008). Effects of long-term training on aided speech-recognition performance in noise in older adults. Journal of Speech, Language, and Hearing Research, 51, 759-771.

De Filippo, C. L. \& Scott, B. L. (1978). A method for training and evaluating the reception of ongoing speech. The Journal of the Acoustical Society of America, 63(4), 1186-1192.

Kim, J. S., Pae, S. Y., \& Lee, J. H. (2000). Development of a test of Korean Speech Intelligibility in Noise (KSPIN) using sentence materials with controlled word predictability. Speech Sciences, 7(2), 37-50.

Kochkin, S. (2005). MarkeTrak VII: Customer satisfaction with hearing aids in the digital age. The Hearing Journal, 58(9), 30-37.

Koo, S. M., Kim, J. S., \& Lim, D. H. (2006). A summary of the census for the disabled in Korea- focusing on the hearing impaired. Audiology, 2(1), 52-57.

Kwon, Y. J. (2013). Effects of 8-week auditory training: compressed speech and speech in noise (unpublished master's thesis). Hallym University of Graduate Studies, Seoul.

Lee, J. \& Lee, K. W. (2008). Breakthroughs in hearing aid technology and rehabilitation. Korean Journal of Audiology, 12, 145-151.

Shin, J. B. \& Lee, J. H. (2010). Effects of the target talker gender and the number of competing talkers on Acceptable Noise Level (ANL) of Korean normal-hearing adults. Audiology, 6(2), 146-152.

Yeo, S. H., Bahng, J., \& Lee, J. H. (2014). Efficacy of auditory training using sentences in noise for hearing aid users. Audiology, 10(1), 65-75. 
APPENDIX

\begin{tabular}{|c|c|c|c|c|c|c|c|c|c|}
\hline \multirow{3}{*}{ No. } & \multirow{3}{*}{ Sentences } & \multirow{3}{*}{$\begin{array}{l}\text { Length of } \\
\text { sentence }\end{array}$} & \multirow{3}{*}{$\begin{array}{c}\text { Validity } \\
\text { score }\end{array}$} & \multicolumn{6}{|c|}{ Correct response rate $(\%)$} \\
\hline & & & & \multicolumn{3}{|c|}{ Sentence without noise } & \multicolumn{3}{|c|}{ Sentence with noise } \\
\hline & & & & Total & Young & Elder & Total & Young & Elder \\
\hline 1 & 나는 처음 듣는 이야기였다. & 4 & 4.6 & 100 & 100 & 100 & 100 & 100 & 100 \\
\hline 2 & 밤기차를 타고 돌아갈 생각이다. & 4 & 4.6 & 100 & 100 & 100 & 100 & 100 & 100 \\
\hline 3 & 컵에 물을 따라 마셨다. & 4 & 4.6 & 100 & 100 & 100 & 100 & 100 & 100 \\
\hline 4 & 시계탑 밑에서 오빠를 기다렸다. & 4 & 4.4 & 100 & 100 & 100 & 100 & 100 & 100 \\
\hline 5 & 현관문을 열고 마당으로 나왔다. & 4 & 4.4 & 100 & 100 & 100 & 100 & 100 & 100 \\
\hline 6 & 한복을 입고 화사하게 웃었다. & 4 & 4.4 & 100 & 100 & 100 & 100 & 100 & 100 \\
\hline 7 & 국은 간이 맞고 겉절이는 고소했다. & 5 & 4.4 & 100 & 100 & 100 & 77.5 & 90 & 65 \\
\hline 8 & 눈물이 그렁그렁 고여 있었다. & 4 & 4.2 & 100 & 100 & 100 & 62.5 & 80 & 45 \\
\hline 9 & 식탁에서 일어나 방으로 들어갔다. & 4 & 4.2 & 100 & 100 & 100 & 100 & 100 & 100 \\
\hline 10 & 엄마가 다시 여동생을 데려왔다. & 4 & 4.2 & 100 & 100 & 100 & 100 & 100 & 100 \\
\hline 11 & 그의 눈엔 예뻐 보였다. & 4 & 4.2 & 100 & 100 & 100 & 100 & 100 & 100 \\
\hline 12 & 엄마의 눈엔 눈물이 고였다. & 4 & 4.2 & 100 & 100 & 100 & 67.5 & 90 & 45 \\
\hline 13 & 상자는 하나가 아니라 두 개였다. & 5 & 4.2 & 100 & 100 & 100 & 100 & 100 & 100 \\
\hline 14 & 얼굴이 환해지고 웃음이 번졌다. & 4 & 4.2 & 100 & 100 & 100 & 67.5 & 90 & 45 \\
\hline 15 & 아빠는 아무 말도 하지 않았다. & 5 & 4.2 & 100 & 100 & 100 & 100 & 100 & 100 \\
\hline 16 & 최소한의 도덕과 예의는 있어야 한다. & 5 & 4.2 & 100 & 100 & 100 & 95 & 95 & 95 \\
\hline 17 & 꼬마가 작은 배낭을 메고 걸어왔다. & 5 & 4.2 & 100 & 100 & 100 & 77.5 & 95 & 60 \\
\hline 18 & 아침에 새로 산 교복을 입었다. & 5 & 4.2 & 100 & 100 & 100 & 95 & 100 & 90 \\
\hline 19 & 그녀의 첫인상은 매우 좋았다. & 4 & 4.2 & 100 & 100 & 100 & 100 & 100 & 100 \\
\hline 20 & 녹차 한 잔을 내밀었다. & 4 & 4.2 & 100 & 100 & 100 & 100 & 100 & 100 \\
\hline 21 & 그는 군복을 입고 있었다. & 4 & 4.2 & 100 & 100 & 100 & 100 & 100 & 100 \\
\hline 22 & 신랑은 오남매 중 막내였다. & 4 & 4.2 & 100 & 100 & 100 & 100 & 100 & 100 \\
\hline 23 & 하루 종일 비가 내렸다. & 4 & 4.2 & 100 & 100 & 100 & 100 & 100 & 100 \\
\hline 24 & 물컵은 개수대에 놓여 있었다. & 4 & 4 & 100 & 100 & 100 & 85 & 95 & 75 \\
\hline 25 & 나는 바닷가의 모래밭에서 일어섰다. & 4 & 4 & 100 & 100 & 100 & 100 & 100 & 100 \\
\hline 26 & 새벽바람이 옷 속으로 파고들었다. & 4 & 4 & 100 & 100 & 100 & 100 & 100 & 100 \\
\hline 27 & 얼른 일어나 부억으로 가보았다. & 4 & 4 & 100 & 100 & 100 & 100 & 100 & 100 \\
\hline 28 & 엄마가 나를 물끄러미 보았다. & 4 & 4 & 100 & 100 & 100 & 100 & 100 & 100 \\
\hline 29 & 다른 길을 모색해야 했다. & 4 & 4 & 100 & 100 & 100 & 100 & 100 & 100 \\
\hline 30 & 그는 고개를 떨구었다. & 3 & 4 & 100 & 100 & 100 & 100 & 100 & 100 \\
\hline 31 & 엄마의 눈이 반짝 빛났다. & 4 & 4 & 100 & 100 & 100 & 100 & 100 & 100 \\
\hline 32 & 간단한 일처럼 순식간에 해냈다. & 4 & 4 & 100 & 100 & 100 & 85 & 95 & 75 \\
\hline 33 & 얼굴에 함박 웃음이 피어났다. & 4 & 4 & 100 & 100 & 100 & 100 & 100 & 100 \\
\hline
\end{tabular}


No. Sentences

Correct response rate (\%)

\begin{tabular}{|c|c|c|c|c|c|c|c|c|c|}
\hline \multirow[t]{2}{*}{ No. } & \multirow[t]{2}{*}{ Sentences } & \multirow{2}{*}{ sentence } & \multirow{2}{*}{ score } & \multicolumn{3}{|c|}{ Sentence without noise } & \multicolumn{3}{|c|}{ Sentence with noise } \\
\hline & & & & Total & Young & Elder & Total & Young & Elder \\
\hline 34 & 여행을 떠나온 소녀 같았다. & 4 & 4 & 100 & 100 & 100 & 100 & 100 & 100 \\
\hline 35 & 아내의 목에서 목걸이가 반짝거렸다. & 4 & 4 & 100 & 100 & 100 & 100 & 100 & 100 \\
\hline 36 & 아내가 깊은 한숨을 내쉬었다. & 4 & 4 & 100 & 100 & 100 & 92.5 & 95 & 90 \\
\hline 37 & 논에 나가 벼를 베었다. & 4 & 4 & 100 & 100 & 100 & 100 & 100 & 100 \\
\hline 38 & 밤에 아버지에게 전화를 걸었다. & 4 & 4 & 100 & 100 & 100 & 100 & 100 & 100 \\
\hline 39 & 오빠는 나를 물끄러미 바라보았다. & 4 & 4 & 100 & 100 & 100 & 100 & 100 & 100 \\
\hline 40 & 큰딸이 새벽에 전화를 걸었다. & 4 & 4 & 100 & 100 & 100 & 100 & 100 & 100 \\
\hline 41 & 나는 엄마와 식탁에 마주 앉았다. & 5 & 4 & 100 & 100 & 100 & 100 & 100 & 100 \\
\hline 42 & 잠시 한숨을 쉬고는 말을 이었다. & 5 & 4 & 100 & 100 & 100 & 100 & 100 & 100 \\
\hline 43 & 동생은 아침 해처럼 밝게 웃었다. & 5 & 4 & 100 & 100 & 100 & 87.5 & 95 & 80 \\
\hline 44 & 우리 남매는 아무 말도 하지 않았다. & 6 & 4 & 100 & 100 & 100 & 100 & 100 & 100 \\
\hline 45 & 그 책은 내가 읽기에도 어려운 책이었다. & 6 & 4 & 100 & 100 & 100 & 80 & 95 & 65 \\
\hline 46 & 나는 자리에서 일어나 불을 켰다. & 5 & 4 & 100 & 100 & 100 & 100 & 100 & 100 \\
\hline 47 & 야식으로 라면을 끓여 먹었다. & 4 & 4 & 100 & 100 & 100 & 92.5 & 95 & 90 \\
\hline 48 & 고개를 좌우로 흔들면서 대답했다. & 4 & 4 & 100 & 100 & 100 & 95 & 100 & 90 \\
\hline 49 & 명함을 꺼내어 그에게 내밀었다. & 4 & 4 & 100 & 100 & 100 & 80 & 90 & 70 \\
\hline 50 & 백화점의 비상벨이 울리기 시작했다. & 4 & 4 & 100 & 100 & 100 & 100 & 100 & 100 \\
\hline
\end{tabular}

